\title{
Pathogenesis of Human Norovirus Genogroup II Genotype 4 in Post- Weaning Gnotobiotic Pigs ${ }^{\mathrm{S}}$
}

\author{
Byung-Joo Park ${ }^{1}$, Soon-Tag Jung ${ }^{2}$, ChangSun Choi ${ }^{2}$, Jinjong Myoung ${ }^{3}$, Hee-Seop Ahn ${ }^{1}$, Sang-Hoon Han ${ }^{1}$, \\ Yong-Hyun Kim ${ }^{1}$, Hyeon-Jeong Go ${ }^{1}$, Joong-Bok Lee ${ }^{1}$, Seung-Yong Park ${ }^{1}$, Chang-Seon Song ${ }^{1}$, Sang-Won Lee ${ }^{1}$, \\ and In-Soo Choi ${ }^{1 *}$
${ }^{1}$ Department of Infectious Diseases, College of Veterinary Medicine, Konkuk University, Seoul 05029, Republic of Korea
${ }^{2}$ Department of Food and Nutrition, College of Biotechnology and Natural Resources, Chung-Ang University, Anseong 17546, Republic of Korea
${ }^{3}$ Korea Zoonosis Research Institute, Chonbuk National University, Jeonju 54896, Republic of Korea

\author{
Received: September 28, 2018 \\ Revised: November 1, 2018 \\ Accepted: November 2, 2018 \\ First published online \\ November 3, 2018 \\ *Corresponding author \\ Phone: +82-2-2049-6055; \\ Fax: +82-2-3436-5880; \\ E-mail: ischoi@konkuk.ac.kr
}

S upplementary data for this paper are available on-line only at http://jmb.or.kr.

pISSN 1017-7825, eISSN 1738-8872

Copyright(C 2018 by

The Korean Society for Microbiology and Biotechnology

\begin{abstract}
Norovirus is the most common cause of acute gastroenteritis. Its pathogenesis is poorly understood owing to the difficulty of establishing viral infection in animal models. Here, postweaning gnotobiotic pigs were infected with human norovirus genogroup II genotype 4 (HuNoV GII.4) to investigate the pathogenesis and replication of the virus. Three groups of four pigs were infected with $1 \times 10^{5}, 1 \times 10^{6}$, or $1 \times 10^{7}$ genomic equivalent (GE) copies of HuNoV GII.4. Four pigs were used as negative controls. Blood and rectal swab samples were collected after viral infection, and gross legions were examined after necropsy. Diarrhea was induced in $25 \%$ and $75 \%$ of pigs infected with $1 \times 10^{6}$ and $1 \times 10^{7}$ GE copies, respectively. Viral shedding was detected in 50\%, 75\%, and 50\% of pigs infected with $1 \times 10^{5}, 1 \times 10^{6}$, and $1 \times 10^{7}$ GE copies, respectively. Viremia was detected in $25 \%$ of pigs infected with either $1 \times 10^{6}$ or $1 \times 10^{7}$ GE copies. When gross lesions of gastroenteritis were investigated, the ileum walls of the infected pigs were thinner than those of the controls. Villi atrophy and inflammatory cell infiltration were identified in the ileum of each infected pig. Viral capsid was identified in the jejunum, ileum, colon, spleen, and mesenteric lymph node. Virus replication was newly verified in the spleen and mesenteric lymph nodes by detection of negative-sense viral RNA. In conclusion, HuNoV GII.4 could induce acute gastroenteritis and replicate in the extraintestinal lymphoid tissues in post-weaning gnotobiotic pigs. Therefore, such pigs would be a suitable animal model for studying the pathogenesis and replication of $\mathrm{HuNoV}$.
\end{abstract}

Keywords: Norovirus, gnotobiotic pig, gastroenteritis, pathogenesis, replication

\section{Introduction}

Viral gastroenteritis caused by human norovirus ( $\mathrm{HuNoV}$ ) infection is a serious foodborne disease worldwide. $\mathrm{HuNoV}$, which belongs to the family Caliciviridae and the genus Norovirus, causes 23 million cases and accounts for over 50,000 hospitalizations per year in the USA [1-4]. Norovirus can infect people of all ages, and infection often follows the consumption of virus-contaminated water or foods [1, 5-7]. In particular, $\mathrm{HuNoV}$ genogroup II genotype 4 (HuNoV GII.4) is the major causative agent of most cases of infection in Korea [8,9]. Since a preventive vaccine is not currently available, the only way of preventing HuNoV infection is consumption of chemically treated clean tap water and heat-treated foods [10-12]. The pathogenesis and replication of $\mathrm{HuNoV}$ is poorly understood because cell-culture systems and proper animal infection models are not available [13, 14].

Gnotobiotic pigs have been used as animal models for the study of pathological features and immunological responses to $\mathrm{HuNoV}$ infection. They are useful as infection models because they have not been exposed to pathogens and have histo-blood group antigens (HBGAs) that are similar to those of humans [15-17]. Most of the initial 
studies of the pathogenesis of $\mathrm{HuNoV}$ have been conducted using newborn gnotobiotic piglets. Those studies provide fundamental information about norovirus infection, such as the optimal titer of the virus, the viral shedding period, the induction of viremia, and the target cells of the virus [16]. Post-weaning gnotobiotic pigs have also been used to reproduce the clinical features of $\mathrm{HuNoV}$ [18]. It was suggested that the maturation status of immunological and physiological systems of post-weaning gnotobiotic pigs would be different from that of newborn piglets [18]. Therefore, it is reasonably expected that the experimental infection of post-weaning gnotobiotic pigs rather than new-born piglets with $\mathrm{HuNoV}$ would reflect infection in young children who are one of the high risk groups for norovirus infections.

There are several controversies pertaining to the tropism of $\mathrm{HuNoV}$ and murine norovirus (MuNoV). Intestinal epithelial cells are known to be the major target of $\mathrm{HuNoV}$. This concept is supported by recent studies that show replication of $\mathrm{HuNoV}$ in stem cell-derived human enteroids and in intestinal tissue from immunocompromised patients [19, 20]. Recently, macrophages, dendritic cells, B cells, and T cells in the gut-associated lymphoid tissue have been suggested as the targets of MuNoV [21-24]. Human B cells were once regarded as potential targets of $\mathrm{HuNoV}$, but other studies could not reproduce these findings [23, 25]. Interestingly, it has been found that $\mathrm{MuNoV}$ can infect lymphoid organs such as the spleen [26, 27]. A recent study also demonstrated the presence of viral capsid protein and RNA genome in lymphatic organs such as tonsil, spleen, and mesenteric lymph nodes of pigs infected with $\mathrm{HuNoV}$ [28]. However, definitive evidence of $\mathrm{HuNoV}$ replication in lymphoid organs seems to require further studies.

In this study, we attempted to define the pathological features and plausible replication organs of HuNoV GII.4 in post-weaning gnotobiotic pigs. HuNoV GII.4 readily induces acute gastroenteritis in post-weaning gnotobiotic pigs, as expected. For the first time, we present evidence of viral replication in lymphoid organs by demonstrating negative-sense viral RNA (NS vRNA), a replicative intermediate antigenome of norovirus. We expect that our results will meaningfully contribute to improved understanding of the pathogenesis and replication of $\mathrm{HuNoV}$.

\section{Materials and Methods}

\section{Virus Preparation}

HuNoV strain KU131206- HuNoV GII.4-obtained from a patient suffering from acute gastroenteritis was used as the infectious agent. The virus stock was diluted 10-fold with minimum essential media (Wellgene, Korea). The diluted solutions were centrifuged at 3,000 $\times g$ for $30 \mathrm{~min}$, and the supernatant was collected. RNA was extracted from the supernatant using a QIAamp viral RNA extraction kit (Qiagen, USA), and the viral RNA was stored at $-70^{\circ} \mathrm{C}$.

\section{Animals and Experimental Design}

A total of 16 4-week-old, post-weaning gnotobiotic pigs were provided by the Bio-organ Research Center, Konkuk University, Seoul, Korea. The experimental procedures were approved by the Institutional Animal Care and Use Committee, Konkuk University, Korea (approval number KU14073). The pigs were adapted for three days at a biosafety level 2-grade facility by providing commercial feed before conducting experiments. All infection experiments were carried out at the biosafety level 2-grade facility located at the College of Veterinary Medicine, Konkuk University. Three groups of pigs (four pigs per group) were orally inoculated with $1 \times 10^{5}, 1 \times 10^{6}$, or $1 \times 10^{7}$ genomic equivalent (GE) copies of $\mathrm{HuNoV}$ GII.4. Four pigs were used as negative controls. Blood and rectal swab samples were collected every day for 3 days after viral infection. All of the pigs were euthanized at day 3 with potassium chloride after administering zolazepam. Gross pathogenic legions of the small and large intestines, mesenteric lymph nodes, and spleen were examined. The collected organs were stored at $-70^{\circ} \mathrm{C}$ and fixed in $4 \%$ formaldehyde.

\section{Clinical Signs and Preparation of Fecal and Serum Samples}

Clinical features of gnotobiotic pigs infected with $\mathrm{HuNoV}$ were determined by the severity of diarrhea for 3 days after infection. The rectal swab samples collected from the gnotobiotic pigs were diluted 1:10 (w/v) with phosphate-buffered saline (PBS). The fecal samples were placed in $1.5-\mathrm{ml}$ microcentrifuge tubes and $500 \mu \mathrm{l}$ of PBS was added. All the diluted samples were centrifugated at $3,000 \times g$ for $30 \mathrm{~min}$, and supernatants were collected. The blood samples were collected from the jugular veins of the gnotobiotic pigs, and the serum samples were separated by centrifugation at 2,000 $\times g$ for $10 \mathrm{~min}$. Viral RNA was extracted from the supernatants from the fecal and serum samples using a QIAamp viral RNA extraction kit (Qiagen).

\section{Detection of Norovirus in Fecal, Serum, and Tissue Samples}

Semi-nested RT-qPCR was conducted using a T100 Thermal Cycler (BioRad, USA) to detect norovirus in the fecal and serum samples. The first RT-qPCR was conducted with a total volume of $20 \mu$ consisting of 10 pmol of each GII-forward 1 (GII-F1) (5'-GGG AGG GCG ATC GCA ATC T-3') and a GII-reverse 1 (GII-R1) (5'CCR CCI GCA TRI CCR TTR TAC AT-3') primer, $5 \mu$ l of RNA sample, and a Maxime RT-PCR premix kit (iNtRON Biotechnology, Korea). The first RT-qPCR conditions were: $45^{\circ} \mathrm{C}$ for $30 \mathrm{~min} ; 94^{\circ} \mathrm{C}$ for $5 \mathrm{~min} ; 25 \mathrm{cycles}$ of $95^{\circ} \mathrm{C}$ for $30 \mathrm{sec}, 50^{\circ} \mathrm{C}$ for $30 \mathrm{sec}$, and $72^{\circ} \mathrm{C}$ for $30 \mathrm{sec}$; and a final extension at $72^{\circ} \mathrm{C}$ for $10 \mathrm{~min}$. The second PCR was conducted using $2 \mu \mathrm{l}$ of the first PCR product 
and a GII-F3 (5'-TTG TGA ATG AAG ATG GCG TCG ART-3') and a GII-R1 primer in a Maxime PCR premix kit (i-star taq) (iNtRON Bio-technology), and the amplification reaction was expected to produce a 310-bp product. The second PCR conditions were: $94^{\circ} \mathrm{C}$ for $5 \mathrm{~min} ; 25 \mathrm{cycles}$ of $95^{\circ} \mathrm{C}$ for $30 \mathrm{sec}, 50^{\circ} \mathrm{C}$ for $30 \mathrm{sec}$, and $72^{\circ} \mathrm{C}$ for $30 \mathrm{sec}$; and a final extension at $72^{\circ} \mathrm{C}$ for $10 \mathrm{~min}$. For detection of NS vRNA, cDNA was synthesized as follows: $10 \mu \mathrm{l}$ of RNA mixture was prepared with 10 pmol of GII-F1 primer, $8 \mu$ l of RNA extracted from spleen and mesenteric lymph node, and $1 \mu \mathrm{l}$ of $10 \mathrm{mM}$ dNTP mix. The RNA mixture was incubated at $65^{\circ} \mathrm{C}$ for $5 \mathrm{~min}$ and then placed on ice for $1 \mathrm{~min}$. The cDNA synthesis mixture was prepared by adding $2 \mu$ of RT buffer to the RNA mixture, with $4 \mu \mathrm{l}$ of $25 \mathrm{mM} \mathrm{MgCl}_{2}, 2 \mu \mathrm{l}$ of $0.1 \mathrm{M} \mathrm{DTT}, 1 \mu \mathrm{l}$ of RNaseOUT, and $1 \mu \mathrm{l}$ of SuperScript III RT (Invitrogen, USA). The cDNA synthesis mixture was incubated at $50^{\circ} \mathrm{C}$ for $50 \mathrm{~min}$ and then at $85^{\circ} \mathrm{C}$ for $5 \mathrm{~min}$. Finally, $1 \mu \mathrm{l}$ of RNase $\mathrm{H}$ was added and incubated at $37^{\circ} \mathrm{C}$ for $20 \mathrm{~min}$. The first PCR amplification was conducted using $5 \mu \mathrm{l}$ of the cDNA and a GII-F1 and a GII-R1 primer pair in a Maxime PCR premix kit (i-star taq) (iNtRON Biotechnology). The PCR conditions were: $94^{\circ} \mathrm{C}$ for $5 \mathrm{~min} ; 25$ cycles of $95^{\circ} \mathrm{C}$ for $30 \mathrm{sec}, 50^{\circ} \mathrm{C}$ for $30 \mathrm{sec}$, and $72^{\circ} \mathrm{C}$ for $30 \mathrm{sec}$; with a final extension at $72^{\circ} \mathrm{C}$ for $10 \mathrm{~min}$. The second PCR conditions were the same as described above.

\section{Determination of Viral Dose}

Quantitative RT-qPCR was used to determine the GE copy of HuNoV GII.4. The reaction was conducted in a $25 \mu$ total reaction volume containing RNase-free water, $5 \mu$ l RNA sample, $12.5 \mu \mathrm{l}$ of $2 \times$ OneStep RT-PCR Buffer III (Takara, Japan), $0.5 \mu \mathrm{l}$ of Ex Taq HS (Takara), 10 pmol of each primer (QNIF2d and COG2R), and 5 pmol of probe (QNIFS) by using previously verified primer and probe sequences $[29,30]$. The RT-qPCR was performed using a SmartCycler II system (Cepheid, USA) as follows: reverse transcription at $42^{\circ} \mathrm{C}$ for $5 \mathrm{~min}$; an initial denaturation at $95^{\circ} \mathrm{C}$ for $10 \mathrm{sec}$; a two-step amplification of 45 cycles; denaturation at $95^{\circ} \mathrm{C}$ for $15 \mathrm{sec}$; and annealing and extension at $60^{\circ} \mathrm{C}$ for $30 \mathrm{sec}$. The GE copy of the virus was calculated based on a standard curve constructed using synthetic HuNoV GII RNA (ATCC, USA).

\section{Hematoxylin and Eosin Staining, and Immunohistochemistry}

The jejunum, ileum, colon, spleen, and mesenteric lymph nodes from each pig were placed in $4 \%$ neutral-buffered formaldehyde and embedded in paraffin by standard methods. Hematoxylin and eosin (H\&E) staining and immunohistochemistry (IHC) assays with the tissue samples were conducted as described previously [28].

\section{Results}

\section{Viral RNA Detection in Serum and Fecal Samples}

As expected, norovirus RNA was not detected in either fecal or serum samples from the negative control pigs (Table 1). Viremia was not detected in the pigs infected with $1 \times 10^{5}$ GE copies of norovirus for the 3 days postinfection (dpi). However, viremia was detected in one out of four $(1 / 4 ; 25 \%)$ of the pigs infected with $1 \times 10^{6} \mathrm{GE}$ copies of norovirus at $3 \mathrm{dpi}$ and in $1 / 4(25 \%)$ of the pigs infected with $1 \times 10^{7} \mathrm{GE}$ copies at $1 \mathrm{dpi}$ (Table 1). Viral shedding was detected in the fecal samples from $2 / 4(50 \%)$, $3 / 4(75 \%)$, and $2 / 4(50 \%)$ of the pigs infected with $1 \times 10^{5}$, $1 \times 10^{6}$, and $1 \times 10^{7}$ GE copies of norovirus during the experimental period, respectively (Table 1 ). These results indicated that $\mathrm{HuNoV}$ successfully infected the postweaning gnotobiotic pigs and was excreted in their feces. Furthermore, systemic infection was induced by viral doses of more than $1 \times 10^{6} \mathrm{GE}$ copies of the norovirus in those pigs.

\section{Clinical Manifestations and Microscopic Lesions}

Clinical manifestations were evaluated for 3 days after norovirus infection according to the severity of diarrhea (Fig. S1). As expected, the negative control pigs did not experience diarrhea. Furthermore, diarrhea was not observed in the pigs infected with $1 \times 10^{5}$ GE copies of norovirus (Table 2). Mild diarrhea was observed in only

Table 1. Number of pigs containing norovirus RNA determined from fecal and serum samples.

\begin{tabular}{ccccccccc}
\hline \multirow{2}{*}{ Virus titer $^{\mathrm{a}}$} & \multicolumn{2}{c}{ Negative } & \multicolumn{2}{c}{$1 \times 10^{5}$} & \multicolumn{2}{c}{$1 \times 10^{6}$} & \multicolumn{2}{c}{$1 \times 10^{7}$} \\
\cline { 2 - 8 } & Serum & Feces & Serum & Feces & Serum & Feces & Serum & Feces \\
\hline $0 \mathrm{dpi}^{\mathrm{b}}$ & $0 / 4(0 \%)$ & $0 / 4(0 \%)$ & $0 / 4(0 \%)$ & $0 / 4(0 \%)$ & $0 / 4(0 \%)$ & $0 / 4(0 \%)$ & $0 / 4(0 \%)$ & $0 / 4(0 \%)$ \\
$1 \mathrm{dpi}$ & $0 / 4(0 \%)$ & $0 / 4(0 \%)$ & $0 / 4(0 \%)$ & $0 / 4(0 \%)$ & $0 / 4(0 \%)$ & $3 / 4(75 \%)$ & $1 / 4(25 \%)$ & $1 / 4(25 \%)$ \\
$2 \mathrm{dpi}$ & $0 / 4(0 \%)$ & $0 / 4(0 \%)$ & $0 / 4(0 \%)$ & $2 / 4(50 \%)$ & $0 / 4(0 \%)$ & $2 / 4(50 \%)$ & $0 / 4(0 \%)$ & $1 / 4(25 \%)$ \\
$3 \mathrm{dpi}$ & $0 / 4(0 \%)$ & $0 / 4(0 \%)$ & $0 / 4(0 \%)$ & $1 / 4(25 \%)$ & $1 / 4(25 \%)$ & $2 / 4(50 \%)$ & $0 / 4(0 \%)$ & $0 / 4(0 \%)$ \\
Total $^{\mathrm{c}}$ & $0 / 4(0 \%)$ & $0 / 4(0 \%)$ & $0 / 4(0 \%)$ & $2 / 4(50 \%)$ & $1 / 4(25 \%)$ & $3 / 4(75 \%)$ & $1 / 4(25 \%)$ & $2 / 4(50 \%)$ \\
\hline
\end{tabular}

${ }^{a}$ Virus titer: viral genomic equivalent (GE) copy number

${ }^{\mathrm{b}}$ dpi: days post-infection

'Total: the number of pigs with viremia in the serum and fecal shedding of the virus detected by reverse transcription polymerase chain reaction (RT-qPCR) in the present study 
Table 2. The number of pigs with clinical signs of diarrhea.

\begin{tabular}{ccccc}
\hline Virus titer $^{\mathrm{a}}$ & Negative & $1 \times 10^{5}$ & $1 \times 10^{6}$ & $1 \times 10^{7}$ \\
\hline $0 \mathrm{dpi}^{\mathrm{b}}$ & $0 / 4(0 \%)$ & $0 / 4(0 \%)$ & $0 / 4(0 \%)$ & $0 / 4(0 \%)$ \\
$1 \mathrm{dpi}$ & $0 / 4(0 \%)$ & $0 / 4(0 \%)$ & $0 / 4(0 \%)$ & $0 / 4(0 \%)$ \\
$2 \mathrm{dpi}$ & $0 / 4(0 \%)$ & $0 / 4(0 \%)$ & $1 / 4(25 \%)$ & $2 / 4(50 \%)$ \\
$3 \mathrm{dpi}$ & $0 / 4(0 \%)$ & $0 / 4(0 \%)$ & $0 / 4(0 \%)$ & $3 / 4(75 \%)$ \\
Total $^{\mathrm{c}}$ & $0 / 4(0 \%)$ & $0 / 4(0 \%)$ & $1 / 4(25 \%)$ & $3 / 4(75 \%)$ \\
\hline
\end{tabular}

${ }^{a}$ Virus titer: viral genomic equivalent (GE) copy number

bdpi: days post-infection

${ }^{\mathrm{c}}$ Total: the number of pigs with clinical signs of diarrhea during the present study

one pig (25\%) infected with $1 \times 10^{6} \mathrm{GE}$ copies of norovirus at $2 \mathrm{dpi}$ (Table 2). Of the pigs infected with $1 \times 10^{7} \mathrm{GE}$ copies of norovirus, two animals (50\%) produced severe watery diarrhea at $2 \mathrm{dpi}$, and one (25\%) had late-onset mild diarrhea at 3 dpi (Table 2); therefore, collectively, there was diarrhea in $75 \%$ of the pigs. These results clearly demonstrated that the typical clinical signs of acute gastroenteritis could be dose-dependently induced in postweaning gnotobiotic pigs infected with $1 \times 10^{6}$ and $1 \times 10^{7}$ GE copies of HuNoV. Gross pathological lesions were identified in the ilea of the infected pigs, but not in the negative controls. The ilea walls of the infected pigs were thinner than those of the negative controls (Fig. S2). Furthermore, the mesenteric lymph nodes of infected pigs were congested (data not shown). Microscopic pathological examination revealed villi atrophy and infiltration of inflammatory cells in the ilea of the infected pigs, but not in the negative controls (Fig. 1). H\&E straining did not reveal
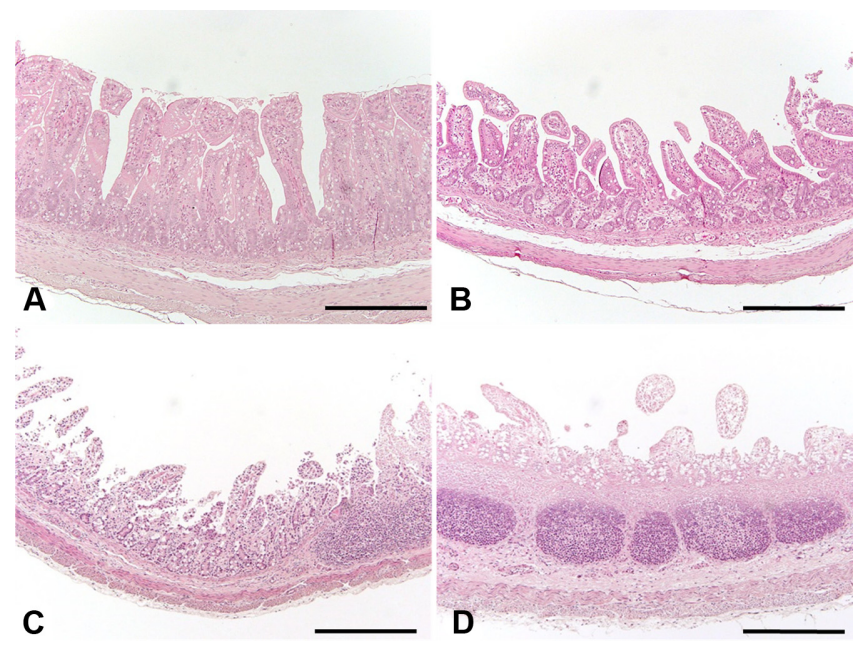

Fig. 1. Histological examination of the ilea from gnotobiotic pigs.

Pathological observations were obtained by H\&E staining of the ileum samples obtained from representative pigs. (A) A negative control (pig \#483) and pigs infected with (B) $1 \times 10^{5}$ (pig \#486), (C) $1 \times$ $10^{6}$ (pig \#493), and (D) $1 \times 10^{7}$ (pig \#495) GE copies of human norovirus. Magnification $\times 200$. Size bar represents $100 \mu \mathrm{m}$.

any other abnormal features in the other organs examined in the present study.

\section{Detection of Norovirus Capsid Protein and Negative- Sense Viral RNA}

The jejunum, ileum, colon, spleen, and mesenteric lymph nodes collected from the pigs in the experimental groups were examined to detect norovirus capsid protein (Fig. 2

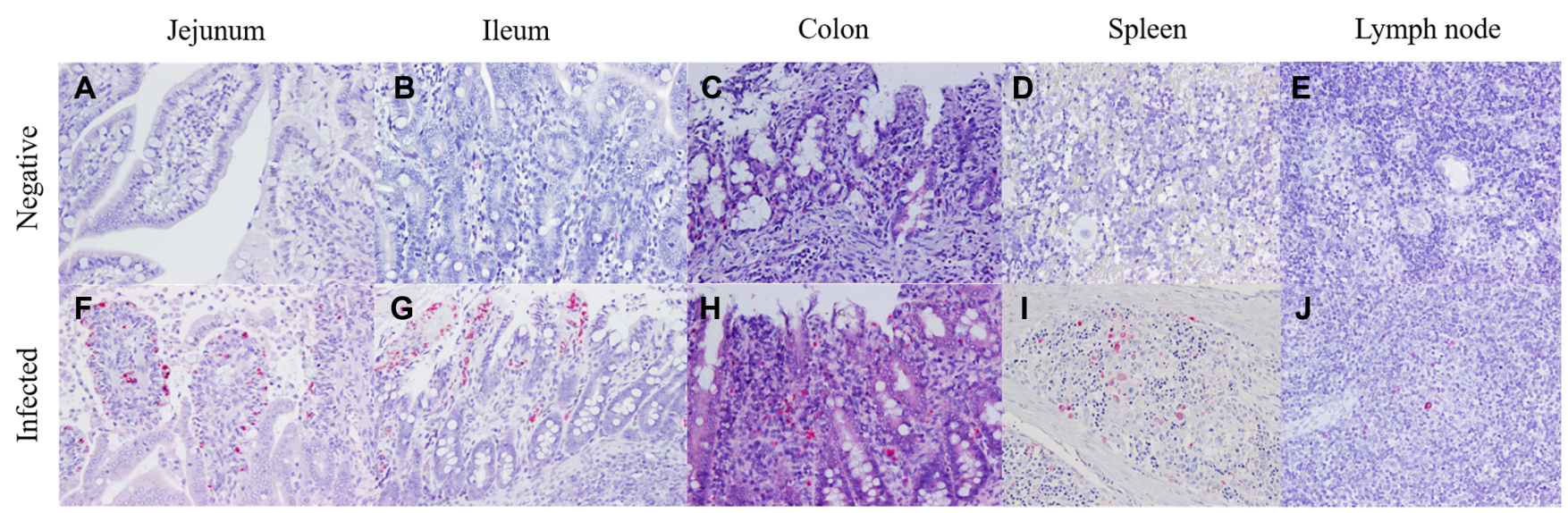

Fig. 2. Detection of human norovirus capsid antigen in gnotobiotic pigs.

Capsid protein was determined by IHC from the intestinal and lymphoid tissue samples obtained from representative pigs. (A) Jejunum, (B) ileum, (C) colon, (D) spleen, and (E) mesenteric lymph node of a negative control pig (pig \#483). (F) Jejunum (pig \#472), (G) ileum (pig \#474), (H) colon (pig \#495), (I) spleen (pig \#495), and (J) mesenteric lymph node (pig \#474) of pigs infected with human norovirus. Magnification $\times 200$. 
Table 3. Detection of viral capsid protein and negative-strand viral RNA in pigs infected with norovirus.

\begin{tabular}{cccccccccc}
\hline \multirow{2}{*}{$\begin{array}{c}\text { Virus } \\
\text { dose }\end{array}$} & Pig & \multicolumn{9}{c}{ Viral capsid protein } & \multicolumn{3}{c}{ NS vRNA $^{\mathrm{a}}$} \\
\cline { 3 - 9 } Control & No. & JE & JE & $\mathrm{IL}^{\mathrm{c}}$ & $\mathrm{CO}^{\mathrm{d}}$ & $\mathrm{SP}^{\mathrm{e}}$ & $\mathrm{ML}^{\mathrm{f}}$ & $\mathrm{SP}$ & $\mathrm{ML}$ \\
& 484 & - & - & - & - & - & - & - \\
& 491 & - & - & - & - & - & - & - \\
& 492 & - & - & - & - & - & - & - \\
\multirow{5}{*}{$1 \times 10^{5}$} & 473 & + & + & - & + & - & + & + \\
& 474 & - & ++ & - & + & ++ & + & + \\
& 485 & ++ & + & - & - & +++ & - & - \\
& 486 & + & ++ & - & - & - & - & - \\
$1 \times 10^{6}$ & 471 & - & - & + & - & + & + & + \\
& 472 & ++ & + & + & ++ & + & + & + \\
& 493 & - & - & - & - & + & - & - \\
& 494 & + & ++ & + & - & + & - & + \\
$1 \times 10^{7}$ & 475 & - & - & + & - & - & - & - \\
& 476 & - & - & + & - & - & - & - \\
& 495 & +++ & + & + & ++ & - & + & - \\
& 496 & - & - & ++ & - & ++ & + & + \\
\hline
\end{tabular}

${ }^{a}$ NS vRNA: Negative-sense viral RNA

${ }^{b} J E$ : Jejunum, ${ }^{c}$ IL: Ileum, ${ }^{d}$ CO: Colon, ${ }^{e}$ SP: Spleen, and ${ }^{\mathrm{f}} \mathrm{ML}$ : Mesenteric lymph node

and Table 3). The viral capsid protein was not detected in any of the tissues collected from the negative control pigs; however, it was identified in all the examined tissues from the norovirus-infected pigs, according to IHC results (Fig. 2). In the pigs infected with $1 \times 10^{5} \mathrm{GE}$ copies of norovirus, viral capsid was detected in the jejunum (75\%), ileum $(100 \%)$, spleen $(50 \%)$, and mesenteric lymph nodes $(50 \%)$, but was not detected in the colon (Table 3$)$. In pigs infected with $1 \times 10^{6} \mathrm{GE}$ copies of norovirus, viral capsid was detected in the jejunum (50\%), ileum (50\%), colon $(75 \%)$, spleen $(25 \%)$, and mesenteric lymph node $(100 \%)$ (Table 3). In pigs infected with $1 \times 10^{7} \mathrm{GE}$ copies of norovirus, the viral capsid was detected in the jejunum $(25 \%)$, ileum $(25 \%)$, colon $(100 \%)$, spleen $(25 \%)$, and mesenteric lymph nodes (25\%). The viral capsid protein was particularly prevalent in the large intestine tissues, depending on the viral dose (Table 3). Viral capsid proteins were located at both the epithelial layers and the lumina of the ilea villi. Capsid proteins were also found in lymphoid organs, such as spleen and mesenteric lymph nodes, and H\&E-stained cells had lymphocyte-like and monocyte-like morphological features (Fig. 3). In order to demonstrate viral replication, the NS vRNA as a replicative
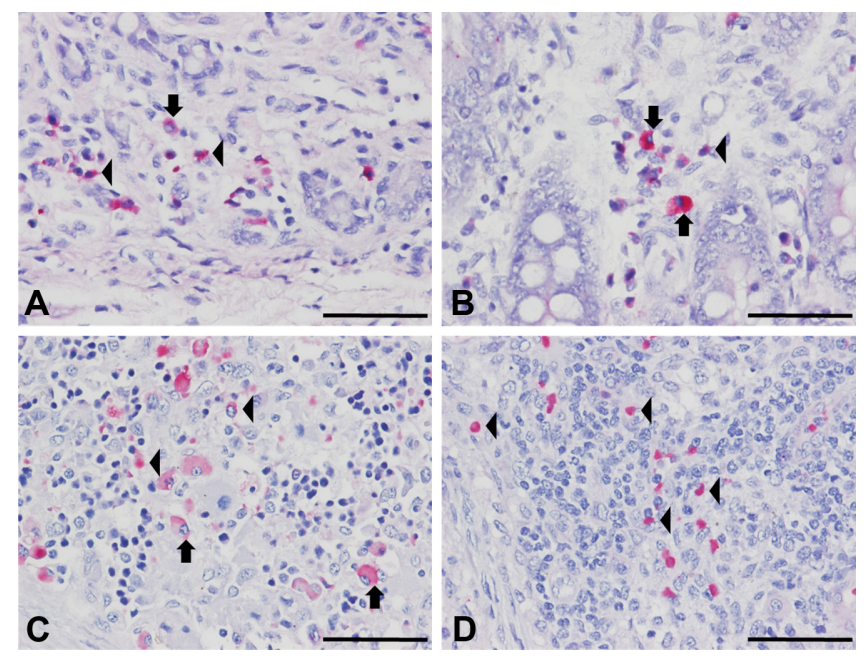

Fig. 3. Determination of cell types infected with human norovirus in gnotobiotic pigs.

Capsid protein was identified by IHC and the cell types were determined by morphological features. (A) Jejunum (pig \#495), (B) colon (pig \#496), (C) spleen (pig \#495), and (D) mesenteric lymph nodes (pig \#496) of pigs infected with $1 \times 10^{7}$ GE human norovirus. Arrows and arrow heads indicate macrophage-like and lymphocytelike cells, respectively. Magnification $\times 400$. Size bar represents $50 \mu \mathrm{m}$.

intermediate anti-genome was detected in the RNA samples extracted from the spleen and mesenteric lymph nodes of the pigs infected with $\mathrm{HuNoV}$ (Table 3). In the pigs infected with $1 \times 10^{5} \mathrm{GE}$ copies of the virus, NS vRNA was determined in $50 \%$ of the spleen and mesenteric lymph node samples. NS vRNA was detected in $50 \%$ of the spleen and $75 \%$ of the mesenteric lymph nodes of pigs infected with $1 \times 10^{6} \mathrm{GE}$ copies of the virus. NS vRNA was found in $50 \%$ of the spleen and mesenteric samples, and in $25 \%$ of the lymph nodes of pigs infected with $1 \times 10^{7} \mathrm{GE}$ copies of the virus.

\section{Discussion}

Norovirus is one of the most important causes of acute gastrointestinal infection. However, the mechanism by which $\mathrm{HuNoV}$ infection occurs remains unclear because proper cell culture systems and animal infection models have been poorly established $[1,13,14]$. Several approaches to develop a cell culture system for $\mathrm{HuNoV}$ infection have been attempted including three-dimensional culturing [13, 19, 23]. There has also been considerable focus on using $\mathrm{MuNoV}$ as an alternative model for understanding the pathogenesis and immune response of $\mathrm{HuNoV}[22,26,27$, 
31]. Since gnotobiotic pigs have HBGAs similar to those of humans and have no experience of exposure to environmental antigens, they have also been used as an alternative animal model for the study of $\mathrm{HuNoV}$ pathogenesis $[17,32,33]$. In the present study, a $\mathrm{HuNoV}$ infection model was established in post-weaning gnotobiotic pigs. Acute gastroenteritis, a typical sign of norovirus infection in humans, was dose-dependently induced in the post-weaning gnotobiotic pigs infected with $\mathrm{HuNoV}$ during a short experimental period. Similarly, post-weaning gnotobiotic pigs were challenged with $\mathrm{HuNoV}$ to verify the viral infectivity and fecal shedding periods [18]. The study demonstrated the induction of diarrhea and fecal viral shedding within 2 days post infection as clinical features of $\mathrm{HuNoV}$ infection in pigs. Therefore, these results collectively verify that $\mathrm{HuNoV}$ could infect and reproduce acute gastroenteritis in postweaning gnotobiotic pigs.

In the present study, the infectivity of $\mathrm{HuNoV}$ was examined using three different doses: $1 \times 10^{5} \mathrm{GE}, 1 \times 10^{6}$ GE, and $1 \times 10^{7} \mathrm{GE}$. There was also an attempt to confirm whether $\mathrm{HuNoV}$ causes viremia in post-weaning pigs. Viremia could not be demonstrated in pigs infected with $1 \times 10^{5}$ GE. However, viremia was observed in pigs infected with $1 \times 10^{6} \mathrm{GE}$ at $3 \mathrm{dpi}$ and in those infected with $1 \times 10^{7} \mathrm{GE}$ at $1 \mathrm{dpi}$. Fecal viral shedding was demonstrated in all three groups, although pigs infected with $1 \times 10^{6} \mathrm{GE}$ and $1 \times 10^{7}$ GE exhibited earlier shedding than pigs infected with $1 \times 10^{5} \mathrm{GE}$. These results indicated the dosedependent infectivity of $\mathrm{HuNoV}$ in post-weaning gnotobiotic pigs. Similar results were reported in another study, in which infection of $\mathrm{HuNoV}$ was only proved in post-weaning gnotobiotic pigs infected with a higher dose of the virus, but not in pigs infected with a lower dose [18]. Therefore, these results indicate that a higher dose of $\mathrm{HuNoV}$ is more effective for inducing infection and eliciting clinical signs in gnotobiotic pigs than a lower dose. No clinical signs were detected in the pigs infected with $1 \times 10^{5}$ GE. However, diarrhea was induced in pigs infected with $1 \times 10^{6} \mathrm{GE}$ and $1 \times 10^{7} \mathrm{GE}$ from $2 \mathrm{dpi}$. The most severe diarrhea was observed in pigs infected with $1 \times 10^{7} \mathrm{GE}$. Therefore, it seems that the clinical signs of norovirus infection were also dose-dependent.

When the internal organs of the pigs were examined, the walls of the ilea of the infected pigs were thin, whereas those of the negative control pigs were normal, without any pathological gross legions (data not shown). Therefore, microscopic legions of the ilea were investigated to determine the severity of the pathological changes in the infected pigs. The villi of the small intestines in the infected pigs were significantly shorter than those of the negative controls. As expected, the most severe villi atrophy occurred in the pigs infected with the higher dose $\left(1 \times 10^{7}\right.$ $\mathrm{GE})$, and less severe legions were detected in the pigs infected with the lower doses of the virus $\left(1 \times 10^{6} \mathrm{GE}\right.$ and $\left.1 \times 10^{5} \mathrm{GE}\right)$. Therefore, it was assumed that the degree of villi atrophy contributed to the severity of the diarrhea. The IHC assay revealed $\mathrm{HuNoV}$ capsid proteins in the jejunum, ileum, colon, spleen, and mesenteric lymph nodes of pigs infected with the HuNoV. The detection rates of the viral capsid antigen were particularly high in the large intestines of infected pigs, and detection was dosedependent. Viral antigens were located at both the epithelial region and inside the villi. These results implied that the virus may penetrate the basal laminar layer beneath the epithelium.

Several studies have revealed that $\mathrm{MuNoV}$ and $\mathrm{HuNoV}$ can be carried through the basal lamina by $\mathrm{M}$ cells, and cause tropism to macrophages, dendritic cells, and B cells $[22,24,27,34]$. The morphological features of cells stained with anti-HuNoV capsid antibody in the jejunum, ileum, colon, spleen, and mesenteric lymph nodes were determined to identify the types of infected cells. The cells stained during the IHC assay appeared to have the morphologic features of lymphocytes and monocytes. Similar results were obtained from the detection of viral antigens in dendritic cells and B lymphocytes of norovirusinfected chimpanzees [35]. The presence of the lymphocyte-like and monocyte-like morphological features suggested that some immune cells might be infected with $\mathrm{HuNoV}$, as with MuNoV, which can infect various immune cells [22, 24, 27, 36]. Despite the evidence for $\mathrm{HuNoV}$ infection of immune organs, there are still controversies as to whether B lymphocytes might be the potential targets of HuNoV, or not [20, 23, 25, 37]. As RAG/IL2RG-deficient gnotobiotic pigs infected with $\mathrm{HuNoV}$ also showed that depletion of immune cells could induce prolonged $\mathrm{HuNoV}$ infection, the role of immune cells in $\mathrm{HuNoV}$ infection and pathogenesis remains complicated [37]. However, the detection of NS vRNA in this study indicated that $\mathrm{HuNoV}$ could infect and replicate in lymphoid organs such as the spleen and lymph nodes. The limitation of this study was not providing definitive evidence of the target cells of HuNoV. We suggested the monocyte-like and lymphocytelike cells in such lymphoid organs might be target cell candidates because they had the capsid protein of $\mathrm{HuNoV}$.

In conclusion, infections with HuNoV GII.4 induced acute gastroenteritis in post-weaning gnotobiotic pigs, 
along with fecal shedding and viremia. The virus could infect both the intestinal tract and lymphatic organs, such as spleen and mesenteric lymph nodes, in which viral replication was verified. Further studies are required to determine how HuNoV infects lymphoid tissues, and its effects on viral pathogenesis.

\section{Acknowledgments}

This study was supported by a grant from the Cooperative Research Program of the Ministry of Food and Drug Safety, Republic of Korea (grant number: 14162MFDS973).

\section{Conflict of Interest}

The authors have no financial conflicts of interest to declare.

\section{Funding Information}

The Cooperative Research Program of the Ministry of Food and Drug Safety, Republic of Korea (grant number: 14162MFDS973).

\section{References}

1. Hall AJ, Lopman BA, Payne DC, Patel MM, Gastañaduy PA, Vinjé J, et al. 2013. Norovirus disease in the United States. Emerg. Infect. Dis. 19: 1198-1205.

2. Maunula L, Roivainen $M$, Keränen $M$, Mäkelä S, Söderberg $K$, Summa M, et al. 2009. Detection of human norovirus from frozen raspberries in a cluster of gastroenteritis outbreaks. Euro. Surveill. 14: 16-18.

3. Atmar RL, Estes MK. 2006. The epidemiologic and clinical importance of norovirus infection. Gastroenterol Clin. North. Am. 35: 275-290.

4. Chen SY, Tsai CN, Lai MW, Chen CY, Lin KL, Lin TY, et al. 2009. Norovirus infection as a cause of diarrhea-associated benign infantile seizures. Clin. Infect. Dis. 48: 849-855.

5. Glass RI, Parashar UD, Estes MK. 2009. Norovirus gastroenteritis. N. Engl. J. Med. 361: 1776-1785.

6. Chan MC, Sung JJ, Lam RK, Chan PK, Lee NL, Lai RW, et al. 2006. Fecal viral load and norovirus-associated gastroenteritis. Emerg. Infect. Dis. 12: 1278-1280.

7. Matthews J, Dickey B, Miller R, Felzer J, Dawson B, Lee A, et al. 2012. The epidemiology of published norovirus outbreaks: a review of risk factors associated with attack rate and genogroup. Epidemiol Infect. 140: 1161-1172.

8. Kim HS, Hyun J, Kim HS, Kim JS, Song W, Lee KM. 2013. Emergence of GII. 4 Sydney norovirus in South Korea during the winter of 2012-2013. J. Microbiol. Biotechnol. 23: 1641-1643.

9. Lee GC, Kim Mj, Kim JI, Lee CH. 2014. Occurrence and molecular characterization of noroviruses in Korean surface water between 2007 and 2010. J. Microbiol. Biotechnol. 24: 556-562.

10. Atmar RL, Bernstein DI, Harro CD, Al-Ibrahim MS, Chen WH, Ferreira J, et al. 2011. Norovirus vaccine against experimental human Norwalk Virus illness. N. Engl. J. Med. 365: 21782187.

11. Luo K, Oh DH. 2015. Synergistic effect of slightly acidic electrolyzed water and ultrasound at mild heat temperature in microbial reduction and shelf-life extension of fresh-cut bell pepper. J. Microbiol. Biotechnol. 25: 1502-1509.

12. Kim EJ, Lee YD, Kim KY, Park JH. 2015. A synergy effect of trisodium phosphate and ethanol on inactivation of Murine Norovirus 1 on lettuce and bell pepper. J. Microbiol. Biotechnol. 25: 2106-2109.

13. Herbst-Kralovetz MM, Radtke AL, Lay MK, Hjelm BE, Bolick AN, Sarker SS, et al. 2013. Lack of norovirus replication and histo-blood group antigen expression in 3dimensional intestinal epithelial cells. Emerg. Infect. Dis. 19: 431-438.

14. Straub TM, Zu Bentrup KH, Coghlan PO, Dohnalkova A, Mayer BK, Bartholomew RA, et al. 2007. In vitro cell culture infectivity assay for human noroviruses. Emerg. Infect. Dis. 13: 396-403.

15. Meurens F, Summerfield A, Nauwynck H, Saif L, Gerdts V. 2012. The pig: a model for human infectious diseases. Trends Microbiol. 20: 50-57.

16. Cheetham S, Souza M, Meulia T, Grimes S, Han MG, Saif LJ. 2006. Pathogenesis of a genogroup II human norovirus in gnotobiotic pigs. J. Virol. 80: 10372-10381.

17. Saif L, Ward L, Yuan L, Rosen B, To T. 1996. The gnotobiotic piglet as a model for studies of disease pathogenesis and immunity to human rotaviruses. Arch. Virol. Suppl. 12: 153-161.

18. Bui T, Kocher J, Li Y, Wen K, Li G, Liu F, et al. 2013. Median infectious dose of human norovirus GII. 4 in gnotobiotic pigs is decreased by simvastatin treatment and increased by age. J. Gen. Virol. 94: 2005-2016.

19. Ettayebi K, Crawford SE, Murakami K, Broughman JR, Karandikar U, Tenge VR, et al. 2016. Replication of human noroviruses in stem cell-derived human enteroids. Science 353: $1387-1393$

20. Karandikar UC, Crawford SE, Ajami NJ, Murakami K, Kou B, Ettayebi K, et al. 2016. Detection of human norovirus in intestinal biopsies from immunocompromised transplant patients. J. Gen. Virol. 97: 2291-2300.

21. Karst SM, Wobus CE. 2015. A working model of how noroviruses infect the intestine. PLoS Pathog. 11: e1004626.

22. Gonzalez-Hernandez MB, Liu T, Blanco LP, Auble H, Payne HC, Wobus CE. 2013. Murine norovirus transcytosis across an in vitro polarized murine intestinal epithelial monolayer 
is mediated by M-like cells. J. Virol. 87: 12685-12693.

23. Green KY. 2016. Editorial commentary: Noroviruses and b cells. Clin. Infect. Dis. 62: 1139-1140.

24. Jones MK, Grau KR, Costantini V, Kolawole AO, De Graaf M, Freiden $\mathrm{P}$, et al. 2015. Human norovirus culture in B cells. Nat. Protoc. 10: 1939-1947.

25. Jones MK, Watanabe M, Zhu S, Graves CL, Keyes LR, Grau $K R$, et al. 2014. Enteric bacteria promote human and mouse norovirus infection of B cells. Science 346: 755-759.

26. Wobus CE, Thackray LB, Virgin HW. 2006. Murine norovirus: a model system to study norovirus biology and pathogenesis. J. Virol. 80: 5104-5112.

27. Wobus CE, Karst SM, Thackray LB, Chang K-O, Sosnovtsev SV, Belliot G, et al. 2004. Replication of Norovirus in cell culture reveals a tropism for dendritic cells and macrophages. PLoS Biol. 2: e432.

28. Seo DJ, Jung D, Jung S, Ha SK, Ha SD, Choi IS, et al. 2018. Experimental miniature piglet model for the infection of human norovirus GII. J. Med. Virol. 90: 655-662.

29. Le Guyader FS, Parnaudeau S, Schaeffer J, Bosch A, Loisy F, Pommepuy M, et al. 2009. Detection and quantification of noroviruses in shellfish. Appl. Environ. Microbiol. 75: 618-624.

30. Kageyama T, Shinohara M, Uchida K, Fukushi S, Hoshino FB, Kojima S, et al. 2004. Coexistence of multiple genotypes, including newly identified genotypes, in outbreaks of gastroenteritis due to Norovirus in Japan. J. Clin. Microbiol. 42: 2988-2995.

31. Seo K, Lee JE, Lim MY, Ko G. 2012. Effect of temperature,
$\mathrm{pH}$, and $\mathrm{NaCl}$ on the inactivation kinetics of murine norovirus. J. Food Prot. 75: 533-540.

32. Huang P, Farkas T, Marionneau S, Zhong W, RuvoënClouet N, Morrow AL, et al. 2003. Noroviruses bind to human $\mathrm{ABO}$, Lewis, and secretor histo-blood group antigens: identification of 4 distinct strain-specific patterns. J. Infect. Dis. 188: 19-31.

33. Cheetham S, Souza M, McGregor R, Meulia T, Wang Q, Saif L. 2007. Binding patterns of human norovirus-like particles to buccal and intestinal tissues of gnotobiotic pigs in relation to $\mathrm{A} / \mathrm{H}$ histo-blood group antigen expression. J. Virol. 81: 3535-3544.

34. Marionneau S, Ruvoën N, Le Moullac-Vaidye B, Clement M, Cailleau-Thomas A, Ruiz-Palacois G, et al. 2002. Norwalk virus binds to histo-blood group antigens present on gastroduodenal epithelial cells of secretor individuals. Gastroenterology 122: 1967-1977.

35. Bok K, Parra GI, Mitra T, Abente E, Shaver CK, Boon D, et al. 2010. Chimpanzees as an animal model for human norovirus infection and vaccine development. Proc. Nat. Acad. Sci. USA 108: 325-330.

36. Perry JW, Taube S, Wobus CE. 2009. Murine norovirus-1 entry into permissive macrophages and dendritic cells is pH-independent. Virus Res. 143: 125-129.

37. Lei S, Ryu J, Wen K, Twitchell E, Bui T, Ramesh A, et al. 2016. Increased and prolonged human norovirus infection in RAG2/IL2RG deficient gnotobiotic pigs with severe combined immunodeficiency. Sci. Rep. 6: 25222. 